\title{
HOUSING AS A POLITICAL PROBLEM
}

\author{
ERNEST J. BOHN*
}

European governments have for many years been interested in the clearance of slums and the providing of adequate housing facilities for the low-income groups of their population. With the exception of a few crusaders, Americans have not generally accepted housing as being a proper governmental function.

When federal funds were made available for slum clearance and low-cost housing, America was totally unprepared to take advantage of the availability of these funds. In characteristic American style, groups everywhere decided that "there should be a law." Therefore housing laws were introduced and enacted in nearly a score of states. Public housing authorities were set up in many localities. Having enacted these laws and having attempted to operate under them, we find ourselves two years later with the construction industry still flat on its back, slums worse than ever, and the low-income group without decent housing facilities. Since money is available and since "we have a law," why has not the problem been solved?

The availability of federal funds for low-cost housing and slum clearance is said to have been made possible through the New Deal. Yet the Emergency Relief and Construction Act of r932, ${ }^{1}$ passed during the administration of President Hoover, provided, in setting up the Reconstruction Finance Corporation, that the R. F. C. be authorized "to make loans to corporations formed wholly for the purpose of providing housing for families of low income or for reconstruction of slum areas, which are regulated by state or municipal laws as to rents, charges, capital structure, rate of return and areas, methods of operation and to aid in financing projects undertaken by such corporations which are self-liquidating in character."

All this before the talk of the New Deal. The availability of R. F. C. funds was due to the desire to put our unemployed millions to work and to the recognition of the fact that the building trades were hit hardest of all groups of workers. The authors of the Act recognized that if the artisans employed in the construction of housing could be put to work, the benefits of a public works program could be distributed to a far greater degree than by any other type of construction.

- A.B., 1924, Adelbert College, Western Reserve University, LL.B., r926, Western Reserve University Law School. Elected member 88th General Assembly Ohio 1928. Elected member Executive Committec Cleveland Bar Association 1928. Elected member Cleveland City. Council r929-31-33. Chairman JointCouncil-Civic Commission on Housing 1932. Chairman the first National Conference on Slum Clearance (Cleveland) r933. Prcsident, National Association of Housing Officials, Chicago.

${ }^{1} 47$ Stat. 5 (1932), 15 U. S. C. A. (Supp.) c. I4. 
The National Industrial Recovery Act was approved by President Franklin D. Roosevelt on June 6 th, $1933 .^{2}$ It, too, provided that among the purposes for which money may be loaned by the Administrator are the "construction, reconstruction, alteration or repair, under public regulation or control, of low-cost housing and slum clearance projects." In Section 203-A of the Act it is provided that "with a view of increasing employment quickly" the Administrator is empowered to "make grants to states, municipalities or other public bodies for the construction, repair or improvement of any such project, but no such grant shall be in excess of thirty per cent of the cost of the labor and materials employed upon such project." Thus the thirty per cent grant that is made available for housing and slum clearance, the one item that makes housing for the low-income group actually possible, is made available in the very words of the Act to "increase employment quickly."

The federal government is primarily interested in low-cost housing and slum clearance because of a desire to put people to work rather than because of a motivating force to accomplish a great social benefit. It is therefore essential to educate and formulate favorable public opinion throughout the land to carry on the work that the federal government has accidently begun.

Then arouse public opinion! And all public opinion must be aroused. · Nothing happens in the field of social and economic improvement. Improvement comes only after years of struggle, and often bloody struggle. The first expressions of public opinion are local. First, we must arouse public opinion in favor of slum clearance and low cost housing in Cleveland, in Chicago, in Atlanta, in New York and in San Francisco before we attempt to arouse national consciousness of the good to be accomplished by the new idea. The public opinion so aroused in Chicago will exert itself in the enactment of local and state laws to encourage, make possible and, if necessary, force by governmental action, the reconstruction of our slums and the providing of adequate housing facilities for the poor. As soon as there is sufficient demand in localities and states throughout the country, and it becomes the policy of governments in the cities and the states, the clearance of slums and the providing of decent housing facilities will become actually a national program.

How can this public opinion be created?

For half a century the social worker has preached the shame of the American slum. For half a century the philanthropist donated either to education and propaganda or actually contributed to the cost of erecting experiments in better housing facilities. Sociologists have offered courses in the universities and many a doctor's thesis on involved phases of the subject has been written. Yet we still have our slums; the poor live in relatively worse housing conditions than ever. Yet, because of the rapid material progress of America, our standard of living has risen rapidly in other respects since the turn of the century. It seems to me that the only solution is actually to interest governments in the subject. Put housing into politics; force

' 48 Stst. 195 (1933), 40 U. S. C. A. (Supp.) c. 8. 
your political party or your statesman to incorporate it in the platform. England has gone further towards a solution than any other country, and the reason for it is that housing is in politics. I have heard many well-intentioned, low-cost housing advocates express the hope that if slum clearance and low-cost housing were ever a reality, it would have to be kept out of politics. In other words, no governmental interference.

We must have one or the other. Either the government will participate in housing, and housing will be subject to all the abuses that other governmental activities are subject to; or, the government will keep out, and we shall have no solution to our housing or slum problems. If the City of Cleveland were to build a housing project in its 2oth ward, it is very possible that an aspirant for the office of alderman would seek to gain the franchise of the tenants of the project on the ground that he would reduce their rent if elected, or that with the change of an administration, all the efficient janitors or scrub women might be removed from their jobs. But then, that is possible in any other governmental activity.

America is faced today with the task of improving its government, rather than keeping government out of activities it should be in.

.If I will be pardoned for drawing upon my own experience, I shall show how one city and state did create public opinion for the enactment of local and state laws which will make housing and slum clearance a reality.' This favorable public opinion is genuine because it has withstood disappointment after disappointment, finally to be rewarded with the actual beginnings of a long range program. Contracts have actually been signed.

For many years civic organizations, architects, city planners and others in Cleveland had studied the subject of slum clearance and housing for the low-income group, but never had the matter gotten beyond the academic discussion stage. True enough, the City of Cleveland had been doing something in the way of slum clearance through its condemnation of dangerous structures. From time to time the AntiTuberculosis League, the Fire Department, and the Building Department embarked upon a campaign of demolition. With a fanfare of trumpets, several dangerous structures would be demolished to prove that the government of the city was interested in slum clearance.

On May 23, 1932, I introduced a resolution ${ }^{3}$ in the City Council requesting the appointment of a Special Councilmanic Committee to study and make recommendations for the solution of the many problems arising out of the existence of our slum and blighted areas. The resolution was adopted and a special committee of five was appointed.

A series of public hearings was immediately begun. The first of the series was devoted to the study of the many social problems which arise out of the existence of slums. Social agencies were represented and the results of several surveys were discussed.

${ }^{2}$ City of Cleveland, Council Res. No. 97934 . 
The second meeting was devoted to a discussion of the deterioration of property values and other investments. The possibility of a rehabilitation of these sections was discussed from an economic point of view as distinguished from the purely social problems involved. A pledge of coöperation was received from investors and banks.

The next session was devoted to an inquiry into the present condition of the building industry-an industry that would be practically at a standstill even if it were not for the present economic stress. Practically all of our large cities have all the office and public buildings, hotels, apartments, and homes needed for the high or intermediate economic groups, and, therefore, little or nothing remains to be built along the lines that this industry has been engaged in during recent years. The builder, architect and material man realize that building homes for the low-income group is the most important chance for the revival of their business, and, therefore, they pledged their coöperation. to any housing project, not only by bringing down costs but by helping to finance such projects.

Another session was set aside for the discussion of European housing projects, as well as operations under the New York Housing Act. The building code was discussed, as was the subject of fire hazard from the point of view of the Safety Department, as well as from that of the underwriters.

One of the most important meetings was the one called for the discussion of labor problems. The President of the Federation of Labor was accompanied by heads of every one of the building crafts of which there are more than one hundred. After a discussion with them of the subjects of jurisdictional disputes, building code changes which may be made necessary by new construction methods, and construction costs, the labor leaders pledged their coöperation in carrying out a housing program. The action of these leaders was endorsed at a meeting of the members of the various crafts at the labor headquarters the following night.

At the very first meeting I made it clear to the community that everyone attending the meetings was to consider himself a member of the Committee and that every one had the right to participate in the deliberations and to help formulate the policies that were eventually to be adopted. Representatives were invited from the principal civic, religious, governmental, trade, real estate, investment, professional, social welfare, and labor organizations in the city. ${ }^{4}$

\footnotetext{
"The organizations invited included the following: Civic: League of Women Voters, Chamber of Commerce, Federation of Womens' Clubs, Adult Educational Association, The American Legion, The Cleveland Foundation, The Citizens' League; Religious: The Cleveland Federated Churehes, and The Catholic Diocese of Cleveland; Governmental: Board of Education, Juvenile Court, County Welfare Committee, City Plan Commission, Board of Zoning Appeals and Board of County Commissioners; Material and trade: Cleveland Builders' Exchange, The Portland Cement Association, The American Institute of Steel Construction, The Common Brick Manufacturers Association, The Lumber Products Bureau; Real estate and investment: Apartment House Owners Association, The Cleveland Real Estate Board, The Building Owners' and Managers' Association, and all the banks; Professional: The American Institute of Architects, The Cleveland Enginecring Society and Cleveland Bar Association; Social and welfare: The Negro Welfare Association, National Council of Catholic Women, National Association for the Advancement of Colored Pcople, The Anti-Tuberculosis League, The Cleveland Welfare Association, The Y. M. C. A., The Y. W. C. A., The Cleveland Health Council, The Association for Criminal Justice, The Associated Charities,
} 
Before many meetings were held, the subject became the principal topic of discussion in the city. Every civic organization, every luncheon group, every church forum, and every radio station desired speakers to discuss this most interesting subject. Public opinion was being aroused!

As a result of these public hearings at which the subjects referred to, as well as other related matters, were thoroughly discussed and the coöperation of all interests was pledged, the Committee published its report recommending among other things the following:

The enactment immediately of housing legislation by the General Assembly of Ohio and by the City of Cleveland; that banks and other investors be called upon to recommend methods of financing housing projects for the low-income group; that architects, engineers, material-men, builders and craftsmen be called upon to submit plans and ideas for both individual and large scale housing for the low-income earning group; that real estate owners and operators recommend size and proper locations for sites for housing for the low-income group, bearing in mind the necessity for cheap land, as well as a desire to rehabilitate neighborhoods; that social agencies and the schools be called upon to devise new methods of social control that will be necessary and to educate the public in the fundamentals of good housing; that a study be made of the changes that are necessary to modernize and adapt to present conditions our building codes and the need for revision of ordinances governing stenches, noise, sanitation and like subjects; that civic organizations, newspapers and the public be called upon to realize that slum clearance and the providing of housing for the low-income group is no longer an academic and theoretical subject for discussion; that with the coöperation of all persons and groups in the community a social rehabilitation of thousands of people can be accomplished, property values can be saved and stabilized, and work can be obtained for many in the building and associated industries by a program of self-liquidating construction.

The original Council Committee, augmented by those citizens who heeded its call and offered testimony and suggestions during the hearings, became the JointCouncil-Civic Committee on Housing and is recognized in the community as the central clearing house heading up the movement for slum clearance and low-cost housing.

The Emergency Relief and Construction Act of 1932 was adopted by Congress while the Committee was conducting its hearings. After a discussion of its provisions the Committee asked the City Council to adopt a resolution ${ }^{6}$

calling upon the Governor of Ohio to include among the purposes for which the special session of the legislature is soon to be called, the enactment of the necessary legislation providing for the creation of limited-dividend housing companies so as to enable such companies and agencies in Ohio to comply with the federal law referred to, and to obtain loans from the Reconstruction Finance Corporation to provide housing for familics of low income and reconstruction of slum areas.

and the many social settlement houses; Labor and contractors' associations: The General Contractors' Association, The Allied Construction Industries, Building Trades Employers' Association, and 'The Cleveland Federation of Labor and all affiliated labor organizations.

City of Cleveland, Council Res. No. 98316. 
Immediately, wheels were set in motion by the Committee to stir up sentiment throughout the state in favor of the enactment of a housing act. Governmental as well as civic organizations adopted resolutions of the same tenor as the one just referred to, and many private citizens throughout the state added their voices by sending letters to the Governor, joining with the City Council of Cleveland in requesting that he include in his call of a special session of the legislature the enactment of a housing act. The result was that, when the third special session of the legislature was called, the Governor amended his original call, and the legislature had its opportunity to enact a State housing act. In the meantime, copies of our report, favorable newspaper editorials, and letters were sent to the members of our State Senate and General Assembly, so that when the bill was presented, favorable opinion was pretty well crystallized.

Members of the Committee drafted a law based upon the New York Act but eliminating many of its provisions and in other ways adapting it to Ohio conditions. Suggestions from persons and organizations in other Ohio cities were considered, and whenever they were found beneficial, they were incorporated in the bill that was finally presented to the State Legislature.

The principal opposition to the bill came from an association of apartment house owners who were fearful that the building projects would increase the already numerous apartment vacancies. Their opposition continued even after it was pointed out that housing projects for the low-income group as contemplated here means replacement of totally inadequate housing with adequate housing for the low-income group, the group that they cannot and will not house.

The greatest opposition to the bill while it was being considered by the Legislature came from the Cincinnati Real Estate Board and from the State Association of Real Estate Boards. Their opposition to the bill came first because of our attempt to get it through a special session of the legislature and because of the provision conferring the right of eminent domain. The Real Estate Board of Cleveland, however, was favorable to the bill.

Something should be said here about influences universally at work in all legislative bodies. First, there is the influence of party organizations. As I suggested earlier, the promotion of housing and slum clearance has been regarded as being of insufficient importance-or, perhaps, of too much importance-to be included in the platforms of our major parties. Those of you who are interested in the enactment of housing legislation will receive neither support nor opposition from party organizations as such. The socially minded and progressive leader or "boss" of the party, legislature, or legislative delegation will help you if you ask him.

Next, there is the influence of the Chief Executive. Clearly in times such as these when the tendency is toward centralization of authority, the executive has even greater influence than ordinarily. Both the Limited Dividend Housing Law ${ }^{6}$ and

- Ohio Laws 1932, 3rd Spec. Sess., H. B. No. 8. 
the Public Housing Authority Law ${ }^{7}$ were enacted during a special session of the Ohio Legislature. Neither could have been considered by the Legislature had it not been for the Governor's willingness to include in his call for the special session the enactment of housing legislation.

Conduct your campaign from all parts of the state; make your demand universal, and your governor will help you. What governor can withstand the request for the enactment of housing legislation by a group such as I have just named?

Next, there is the power of organized lobby, and I am speaking of the legitimate lobby-the one which acts as a fact-finder for the legislator. Let me give you an example: Real estate boards have, on more than one occasion, opposed slum clearance on the theory that it destroys property values, that no lasting benefits can come from it, and that slum clearance merely means the moving of slums. The Ohio Association of Real Estate Boards has opposed slum clearance, as have real estate boards in most cities in Ohio. Realizing this, one of the first groups that I talked to about the program we had in mind was the Cleveland Real Estate Board. After presenting my arguments and asking them for their aid, I found the officials a group of very socially-minded and far-sighted persons. Let me quote part of a letter received from them:

We have been, for a number of years, endeavoring to find a practical way to work out that difficult area of blight, as well as slums. It is rapidly poisoning other parts of metropolitan Cleveland. The real estate, mortgage and dwelling designing problems involved have had our consideration but by no means are they the whole story. If the Council feels that under the pressure of present conditions they can begin a consideration of this pro. gram, which will take years to solve, you will find us "ready, willing and able" to provide the assistance resulting from our contact with this situation.

Needless to say, this offer of assistance was accepted, and on more than one occasion it was pointed out to the community that here was one of the most sociallyminded organizations, not only in the city, but in the state.

We went to the State Capitol. The Governor included in his call for a special session of the Legislature the enactment of a State Housing Law. Our bill was in fairly good shape, and things moved very rapidly. The representative of the Cleveland Real Estate Board appeared before the Committee and urged its adoption, as a benefit to property interests. The bill was reported out of Committee and then, for the first time, the State Association recognized what was going on. The lobby became in earnest. Charges of railroading were made. I immediately asked the Chairman of the Committee to reconsider the bill, in spite of the fact that the Committee had reported it out favorably and was willing to stand by its decision. That took the wind out of the sails of the opposition. They were put upon the defensive. Their cry of distressed real estate was of no avail because the Committee had already heard, the day before, from the representative of the real estate board of the State's largest city, that slum clearance was the one solution for the rehabilitation of, and

'Ohio Laws I933, Ist Spec. Sess., H. B. No. I9. 
the return of sound values to, real estate, though it might mean the wiping out of speculation.

I need spend little time in speaking of the influence of the newspapers. Everyone knows the enormous power that they wield. During our work we never 'scooped' a newspaper. Whenever we provided a story for the evening papers, we had a new story for the morning papers. Whatever action was taken, the newspapers were informed, and if there was some reason why the matter at hand should not be divulged, they were informed but asked to withhold publication for the time being. Very frankly, a request was made for editorial support, and it was forthcoming. Our project received unanimous editorial support in the large cities. Copies of editorials were sent to newspapers in small towns with the request for favorable consideration. Copies of stories and editorials, as well as other informative literature, were sent to the legislators so that when they arrived at the State Capitol, they had the matter pretty well in hand.

Another most important influence in legislation, of course, is the Speaker. Have the "gavel" with you, and you can often dispense with flowery orations. I well remember an incident that happened during the days preceding the passage of the Public Housing Authority Law. The Committee had reported the bill out favorably, and it was on the calendar for a certain day. The members of the State Legislature were in an ugly mood that morning. They had come down to the State Capitol hoping to have a very definite program available for them on a taxation matter. The program was not ready. Expenses of living at the capital were piling up without additional compensation. Bill after bill went down to defeat that day. Realizing what was happening, the manager of the bill requested that the bill be not considered until the next legislative session. The speaker agreed. The next day was calmthe sun was shining-a program was in the making, and the law in which we were interested was passed. Had the bill come up the day before it might have been defeated. Persuade the Speaker that your bill is a good one.

A most important thing to remember is that you can never be sure that your support will stay with you forever. An important civic organization of Cleveland approved and urged the passage of a limited dividend housing law. You might infer, therefore, that this organization was interested in housing and in slum clearance and would be in favor of any legislation furthering it. The Governor agreed very suddenly that he would include in his call for a special session of the legislature the enactment of a public housing authority law. The bill was drafted in a hurry and introduced in the State Legislature. I was home over that week-end and was requested to meet with the Committee on City Planning of this organization and explain the bill. The bill was explained, some suggestions were made, but the - Committee approved and recommended that the organization support the bill-strictly in keeping with what was believed to be the organization's policy of supporting slum clearance. Several days later, however, another meeting was called of the Com- 
mittee. The notice advised them that, although at a former meeting of the Committee it was voted to recommend approval of the bill, "further study by the Committee is feasible since action on this bill by the Legislature is not imminent." While this notice was being drafted and sent, the legislation was being adopted in Columbus, so that the following day the committee meeting had to be cancelled because, as the notice said, "House Bill No. I9, the so-cailed County Authority Housing Bill, has been approved by both the House and Senate of the Ohio State Legislature." What happened, of course, was this: although this civic organization was willing to approve limited-dividend housing, the conservative members were not ready, without a very long, deliberate, and careful discussion and analysis by its legislative and executive committee, to approve a public housing authority law. There are a lot of conservative people in America who are fearful that public housing smacks too much of socialism.

May I issue a warning to those states that have housing laws? Unless you are able very rapidly to demonstrate the social and economic value of those laws and carefully develop a sound and favorable public opinion, you are risking repeal of your laws at the next regular session of your state legislatures.

The object of this discussion has been an attempt to show that housing is not yet definitely an accepted governmental function; that federal money is available only because of a desire to alleviate unemployment. If there is a desire among us that government should concern itself in low-cost housing and slum clearance (and I believe that a solution is possible only if the government is so concerned by the giving of financial aid through a subsidy in one form or another) then favorable public opinion must first be aroused. I have tried to show by the experiences of Cleveland and Ohio how government can be made to interest itself in the subject, first, by enacting a limited dividend housing law, and then by a natural evolutionary process, a public housing authority law which makes low-cost housing and slum clearance very definitely a public function.

Finally, an aroused public opinion has carried us through all the disappointments until today Cleveland can report projects actually under way with the aid of government money. The failure or the success of these first experimental projects undertaken by the government will in a large measure depend upon the support that government receives from an intelligent public opinion. 